\title{
Charities win and lose on hospital mergers
}

London. British medical research charities fear that they may be asked to foot part of the bill for the surprise decision to make St Thomas's Hospital in London - and not Guy's Hospital - the primary site for a single merged institution.

Under proposals announced last week by Mrs Virginia Bottomley, the health secretary, for the reorganization of London hospitals, acute and specialist services of the two hospitals would be concentrated at St Thomas's, while Guy's would evolve into a "high quality health and academic campus".

But Bottomley did not make any promises that steps would be taken to ensure that clinical researchers at Guy's can move to St Thomas's with the patients who form the basis of their work.

The Imperial Cancer Research Fund (ICRF), which has invested $£ 1.7$ million in a new unit to support the charity's research into breast cancer at Guy's, has expressed particular concern over the plans.

"We have asked for reassurances that we will get equivalent facilities at St Thomas's

\section{Accounting rules meet with relief}

London. University staff in Britain say they have been relieved by the details of plans published last week to introduce greater accountability into the way in which universities and other higher education institutes make use of government grants.

The proposals have been published by the Higher Education Funding Council of England (HEFCE), and outline how universities will be expected to provide the council with an annual breakdown of the allocation of their block grant to departments and faculties from July 1995.

But universities will not be asked for a detailed breakdown of factors such as staff costs and project grants. The aim is "not to impose undue administrative costs on institutions", says Roger Grinyer, an information officer for the HEFCE.

Paul Cottrell, assistant general secretary of the Association of University Teachers, says that the union recognizes that the government has a right to know how its grants are being spent, but had been concerned at the prospect of a mechanism that would allow politicians to veto particular projects. "The only thing that worries us now is the hint that if the internal allocation does not tie in with government priorities, then action could be taken," says Cottrell.

But any such sinister motives are denied by the HEFCE, which explains that the paragraph in question is intended to ensure that future grants go where they are most needed. for our new research programme," says Nick Wright, director of clinical research at the ICRF. "We are waiting for a reply from the minister of health, but if we don't get what we want we will have to ask for our money back."

The unit is to be contained in the United Medical and Dental Schools (UMDS) formed by the merger of the medical schools of both hospitals. It was to have been located in Philip Harris House, a state-of-the-art building originally designed to house clinical researchers from UMDS and patient-care facilities, including day-care and outpatient clinics and an acute mental health-care unit.

Trust funds and charities have pledged to pay about a third of the $£ 142$ million cost of the building. But many - including the Special Trustees of Guy's Hospital who have promised around $£ 24$ million - are reviewing their donations.

"When the public dips into their pockets to give money to the ICRF they do not expect to be paying for government decisions to merge hospitals," says Wright.

So far, nothing has been decided about the future of Philip Harris House, although one scenario is that the UMDS will take over the top two floors and one third of the other three, while the remaining space will be used to house the primary-care facilities outlined by Bottomley.

She has asked Sir Timothy Chessells, chairman of the London Implementation Group, to convene a working party to look at the costs of reorganizing facilities at the two sites.

Lynn Carlisle, head of research services at UMDS, said it would be like "one of those Chinese word games" with a lot of shuffling of research groups between the different sites. "There is the potential for building something quite special in the long term," she says. "However, most of the thousand or so researchers here will be affected, and we are going to have a couple of years of significant disruption."

Bottomley had more surprises up her sleeve when she announced that the Royal Marsden Hospital in west London would be granted trust status. The hospital, which has close links with the Institute of Cancer Research, had been recommended for closure by government-appointed review bodies last June.

The Cancer Research Campaign (CRC), which provides about $£ 10$ million a year to fund research in the Chester Beatty Laboratories at the institute, announced that it was "very happy" to be able to shelve contingency plans that had been made to move research out to the hospital's other site, about 12 miles away at Sutton in Surrey.

No decision has been reached on the future of the Charing Cross and Hammersmith hospitals. These have applied for joint trust status, although the precise arrangements will depend on the outcome of a study being undertaken by Sir David Phillips, former chairman of the Advisory Board for the Research Councils, and Sir Rex Richards, a former vice-chancellor of the University of Oxford.

Fiona Gammie

\section{China and Taiwan build science links}

Tokyo \& Beijing. The exchange of scientists between Taiwan and mainland China is beginning to grow rapidly, despite severe government restrictions on links between the long-estranged neighbours.

Earlier this month, the topic of scientific and technological exchanges featured on the agenda of semi-official talks in Beijing between Taiwan and China, reflecting the growing links in this area.

It was the second such meeting following a ground-breaking summit in Singapore last April, although it still highlighted the huge political gulf that still exists between the two rival Chinese governments, and little substantial agreement emerged.

Since 1989, Taiwan's National Science Council (NSC), a leading government body for funding research, has supported a small but growing programme to encourage links with the mainland. It started with sponsorship of scientists from Taiwan to attend international conferences in China, and now includes funds for short-term visits of a few months by scientists from either side.

The programme has sponsored a number of cross-strait science and technology conferences. Almost US\$1 million has been invested in the programme by the Taiwanese government, and about 300 scientists from both sides have been supported since its start.

In January, a 25-member mainland delegation headed by Zhou Guang-Zhao, president of the Chinese Academy of Sciences, attended a cross-strait conference on steel and material sciences in Taiwan. The delegation later reported that it had been struck by the enthusiasm on both sides to promote cooperation in science and technology.

But there are still many government restrictions hindering such exchange, particularly on Taiwan's side. There are no direct flights between the two countries and last month's delegation had to travel via Hong Kong. Similarly there are only indirect postal, telephone, and fax links with the mainland.

David Swinbanks and You Qin LI 